\title{
DEWAN DIREKSI, CASH HOLDING, NILAI PERUSAHAAN: PERAN MODERASI DARI LEVERAGE
}

\author{
Richard Emanuel $^{1)}$; Jenifer Antonius ${ }^{2)}$; Reinardus Prasetyo Apriyanto ${ }^{3)}$; Amrie Firmansyah $\left.{ }^{4}\right)^{*}$; Estralita \\ Trisnawati ${ }^{5}$ \\ 1) richard.127211022@stu.untar.ac.id, Magister Akuntansi Universitas Tarumanagara \\ 2) jinjeniferantonius@gmail.com_Magister Akuntansi Universitas Tarumanagara \\ ${ }^{3}$ reinardus.127211001@ @tu.untar.ac.id, Magister Akuntansi Universitas Tarumanagara \\ 4)amrie@pknstan.ac.id, Politeknik Keuangan Negara STAN \\ 5) estralitat@fe.untar.ac.id, Magister Akuntansi Universitas Tarumanagara \\ *penulis korespondensi
}

\begin{abstract}
This study aims to find empirical evidence of the effect of cash holding and the size of the board of directors on firm value. In addition, this study also includes leverage in this relationship. This study employs data from companies in the consumer goods industry listed on the Indonesia Stock Exchange from 2015 to 2020. The research data were obtained from www.idx.co.id, www.financial.yahoo.com, and the company's official website. The sample used in this study amounted to 108 observations based on purposive sampling. Research data was tested using multiple regression analysis with panel data. The study results prove that cash holding has a positive effect on firm value, while the size of the board of directors has a negative impact on firm value. Furthermore, leverage weakens the positive effects of cash holding on firm value and strengthens the negative impact of the board of directors' size on firm value. This study indicates that the Indonesia Financial Services Authority needs to re-regulate the implementation of corporate governance, especially concerning the requirements for the board of directors and debt ownership in listed companies in Indonesia.
\end{abstract}

Keywords: Liquidity, Governance, Capital Structure, Debt Policy, Investor Response

\begin{abstract}
Abstrak
Penelitian ini bertujuan untuk menemukan bukti empiris pengaruh cash holding dan ukuran dewan direksi terhadap nilai perusahaan. Selain itu, penelitian ini juga memasukkan leverage dalam hubungan tersebut. Penelitian ini menggunakan data perusahaan sektor industri barang konsumsi yang terdaftar di Bursa Efek Indonesia tahun 2015 sampai dengan 2020. Data penelitian diperoleh dari www.idx.co.id, www.financial.yahoo.com, dan website resmi perusahaan. Berdasarkan purposive sampling, sampel yang digunakan dalam penelitian ini berjumlah 108 observasi. Pengujian data penelitian dilakukan menggunakan analisis regresi berganda dengan data panel. Hasil penelitian membuktikan bahwa cash holding berpengaruh positif terhadap nilai perusahaan, sedangkan ukuran dewan direksi berpengaruh negatif terhadap nilai perusahaan. Selanjutnya, leverage memperlemah pengaruh positif cash holding terhadap nilai perusahaan dan memperkuat pengaruh negatif ukuran dewan direksi terhadap nilai perusahaan. Penelitian ini mengindikasikan bahwa Otoritas Jasa Keuangan perlu mengatur kembali penerapan tata kelola perusahaan khususnya terkait dengan persyaratan dewan direksi dan kepemilikan utang pada perusahaan terbuka di Indonesia.
\end{abstract}

Kata kunci: Likuiditas, Tata Kelola, Struktur Modal, Kebijakan Utang, Respon Investor

\section{PENDAHULUAN}

Kemampuan perusahaan untuk mempertahankan kelangsungan hidup perusahaan merupakan suatu hal yang penting kepada para pemangku kepentingan dalam perusahaan tersebut (Firmansyah, Febrian, Jadi, et al., 2021). Suatu perusahaan membutuhkan dukungan dari berbagai pihak untuk mempertahankan keberlangsungannya di masa depan (Firmansyah, Setiawan, et al., 2020). Informasi atas kondisi perusahaan dapat dapat tercermin dalam harga saham di pasar modal (Ihsani et al., 2021). Informasi yang diberikan oleh perusahaan kepada investor dapat dianggap sebagai good news ataupun bad news (Scott, 2015). Investor mengharapkan investasi yang dialirkan kepada perusahaan dapat memberikan imbal hasil yang 
menguntungkan (Bahrun et al., 2020). Selain itu, analisis keberlangsungan perusahaan di masa depan menjadi penting bagi investor dalam pengambilan keputusan investasi (Firmansyah, Utami, et al., 2020).

Kinerja perusahaan yang tercermin di pasar modal merupakan perwujudan dari nilai perusahaan (Firmansyah \& Purnama, 2020). Investor dapat merespon bahwa informasi yang disajikan oleh perusahaan baik berupa data dan informasi keuangan dan keuangan dapat digunakan oleh investor dalam pengambilan keputusan. Informasi tersebut dapat berupa sinyal yang dapat digunakan oleh investor dalam menilai kondisi perusahaan atau kebijakan tertentu dari perusahaan. Apabila informasi tersebut sejalan dengan ekspektasi investor, makan investor akan meresponnya secara positif. Nilai perusahaan merupakan perwujudan atas kinerja yang dihasilkan oleh manajer yang sejalan dengan harapan investor atas kondisi perusahaan di masa mendatang. Oleh karena itu, ulasan nilai perusahaan perlu diinvestigasi lebih lanjut.

Penelitian sebelumnya yang telah menguji nilai perusahaan dilakukan dengan karakteristik perusahaan seperti, profitabilitas (Kusuma \& Priantinah, 2018; Mubyarto, 2020), ukuran perusahaan (Bing \& Li, 2019; Carolina et al., 2020), intellectual capital (Gaol et al., 2021), cash holding (Bahrun et al., 2020; Cheryta et al., 2018; Firmansyah, Setiawan, et al., 2020; Toly et al., 2019). Selain itu, nilai perusahaan dalam penelitian sebelumnya diuji dengan kebijakan manajer seperti leverage yang merupakan kebijakan perusahaan untuk memilih pendanaan dengan utang (Bahrun et al., 2020; Bing \& Li, 2019; Cheryta et al., 2018; Haryanto et al., 2018; Hertina et al., 2019; Nasution, 2020), kebijakan perusahaan atas investasi pada instrumen derivatif (Firmansyah \& Purnama, 2020; Novianti \& Firmansyah, 2020), perencanaan pajak (Irawan \& Turwanto, 2020; Permatasari et al., 2021; Widodo \& Firmansyah, 2021), kebijakan akrual yang dijalankan manajer (Novianti \& Firmansyah, 2020; Permatasari et al., 2021), kebijakan dividen (Salman et al., 2020). Selain itu, penelitian sebelumnya juga telah menguji nilai perusahaan dengan komponen tata kelola perusahaan seperti kepemilikan manajerial (Firmansyah, Jadi, \& Sukarno, 2021; Widianingsih, 2018), dewan direksi (Mawei \& Tulung, 2019; Sari \& Ardiana, 2014; Sondokan et al., 2019; Utomo \& Dianawati, 2017), kepemilikan institusional (Jamil et al., 2019; Nuryono et al., 2019; Widianingsih, 2018), komisaris independen (Nuryono et al., 2019; Widianingsih, 2018), komite audit (Nuryono et al., 2019; Widianingsih, 2018).

Selanjutnya, penelitian lainnya menguji nilai perusahaan dengan pengungkapan tata tata kelola perusahaan (Firmansyah, Febrian, Jadi, et al., 2021; Firmansyah, Husna, et al., 2021; Firmansyah, Setiawan, et al., 2020; Gaol et al., 2021; Putri et al., 2020). Pengujian nilai perusahaan dengan kebijakan pengungkapan informasi tertentu juga dilakukan dengan pengungkapan pihak berelasi (Dresti \& Putri, 2021; Firmansyah \& Ardi, 2020), pengungkapan keberlanjutan atau tanggung jawab sosial perusahaan (Amalia et al., 2021; Firmansyah, Febrian, Jadi, et al., 2021; Firmansyah, Husna, et al., 2021; Gaol et al., 2021; Hadi et al., 2021; Ihsani et al., 2021; Machmuddah et al., 2020; Rahman et al., 2021), pengungkapan karbon (Firmansyah, Jadi, Febrian, et al., 2021).

Kebijakan manajer dalam mengelola kas perusahaan merupakan salah satu kebijakan terkait dengan strategi manajer dalam menjalankan perusahaan. Kas merupakan aset lancar yang paling likuid yang dapat segera dapat digunakan untuk transaksi perusahaan (Kieso et al., 2018). Manajer dapat menggunakan kas yang tersedia untuk berbagai kebutuhan perusahaan 
seperti memenuhi kewajiban lancar dan kewajiban jangka panjangnya, investasi perusahaan ataupun untuk mengakuisi aset tetap. Kebijakan atas pengelolaan kas merupakan salah satu kebijakan penting terkait dengan keberhasilan manajer dalam pengelolaan perusahaan. Informasi atas komposisi manajer atau dewan direksi dan kas yang dimiliki oleh perusahaan merupakan informasi yang penting bagi investor dalam menambah analisisnya terkait dengan keputusan investasi. Oleh karena itu, pengujian cash holding dan ukuran dewan direksi terhadap nilai perusahaan menjadi penting untuk dilakukan.

Jumlah kas yang dimiliki oleh suatu perusahaan berkaitan dengan tingkat likuiditas perusahaan (Firmansyah, Setiawan, et al., 2020). Bahrun et al. (2020), Cheryta et al. (2018), Firmansyah, Setiawan, et al. (2020), dan Toly et al. (2019) menemukan bahwa cash holding dapat menurunkan nilai perusahaan, Sebaliknya, Dewi et al. (2018), dan Yuliana (2020) menyimpulkan bahwa jumlah kas yang dimiliki oleh perusahaan dapat meningkatkan nilai perusahaan. Adanya perbedaan hasil pengujian sebelumnya mengakibatkan perlunya pengujian kembali atas cash holding terhadap nilai perusahaan.

Selanjutnya, dewan direksi adalah pimpinan perusahaan yang memiliki kewenangan dalam mengendalikan dan mengawasi penggunaan sumber daya agar perusahaan (Sari \& Ardiana, 2014). Keputusan dewan direksi pada umumnya dianggap keputusan terbaik yang ditujukan agar perusahaan dapat menjalankan kegiatan operasional secara efektif dan efisien sehingga dapat meningkatkan nilai perusahaan tersebut dan memikat para investor untuk berinvestasi pada perusahaan tersebut. Carolina et al. (2020) dan Utomo \& Dianawati (2017) menyatakan bahwa ukuran dewan direksi berpengaruh negatif terhadap nilai perusahaan, sedangkan Mawei \& Tulung (2019), Sari \& Ardiana (2014), dan Sondokan et al. (2019) menemukan bahwa ukuran dewan direksi tidak berpengaruh terhadap nilai perusahaan.

Penelitian ini bertujuan untuk menguji pengaruh cash holding dan ukuran dewan direksi terhadap nilai perusahaan. Selain itu, penelitian ini juga memasukkan leverage sebagai variabel moderasi dalam hubungan antara variabel independen dan variabel dependen yang masih jarang digunakan dalam penelitian sebelumnya. Kebijakan utang merupakan kebijakan manajer dalam mendanai perusahaan yang bersumber dari utang. Adanya kebijakan utang tersebut dapat meningkatkan informasi asimetri antara manajer dan pemegang saham (Firmansyah, Fauzi, et al., 2020). Perusahaan akan lebih transparan terkait dengan kondisi keuangan perusahaan kepada kreditor dalam rangka mendapatkan pendanaan perusahaan yang bersumber dari utang. Namun, penggunaan utang yang lebih besar dapat meningkatkan risiko kebangkrutan perusahaan di masa mendatang (Firmansyah, Utami, et al., 2020). Haryanto et al. (2018), Hertina et al. (2019), dan Nasution, 2020) menemukan bahwa pendanaan dengan utang dapat menurunkan nilai perusahaan. Apabila manajer tidak optimal dalam mengelola utang, perusahaan akan terancam keberlangsungannya di masa depan karena adanya potensi kebangkrutan atas kewajiban yang harus dipenuhi.

\section{KAJIAN LITERATUR}

Cash holding yang tinggi dalam suatu perusahaan dapat menimbulkan konflik keagenan antara manajer dan pemegang saham. Manajer memiliki kepentingan untuk mendapatkan gaji dan bonus yang besar. Sementara itu, prinsipal memiliki kepentingan untuk mendapatkan pengembalian modal setinggi-tingginya. Di sisi lain, perusahaan memerlukan jumlah kas 
tertentu yang diperlukan untuk memenuhi kewajiban jangka pendeknya, kewajiban kontijensi dan peluang potensi investasi tertentu (Firmansyah, Setiawan, et al., 2020). Cash holding yang tinggi dapat meminimalisir resiko dari biaya utang yang tinggi, sehingga membuat kondisi perusahaan menjadi lebih stabil (Putra \& Rahmawati, 2016). Harga saham perusahaan menjadi lebih tinggi ketika terdapat kemungkinan pembayaran dividen tunai dalam waktu dekat. Selain itu, perusahaan dengan banyak cash holding akan menunjukkan kemampuan untuk menghasilkan arus kas dari operasi bisnis serta kemampuan yang baik untuk memenuhi pembayaran hutang dan pengeluaran yang lebih baik (Dewi et al., 2018; Yuliana, 2020).

Di sisi lain, pemegang saham menganggap bahwa perusahaan dengan kepemilikan kas yang tinggi dianggap tidak memiliki strategi dalam menginvestasikan ke dalam aset-aset yang produktif (Al 'Alam \& Firmansyah, 2019; Firmansyah \& Triastie, 2020; Kurniawan \& Firmansyah, 2019). Selain itu, perusahaan dapat mengembangkan perusahaan dengan melakukan akuisisi perusahaan lain melalui jumlah kas yang tersedia lebih besar (Suhanda et al., 2019). Jumlah kas tersedia yang besar dimiliki oleh menunjukkan kebijakan yang tidak sejalan dengan harapan pemegang saham karena dianggap bahwa perusahaan belum berhasil menerapkan strategi dalam menginvestasikan kembali kas tersebut. Akibatnya perusahaan yang memiliki jumlah kas yang besar malah menurunkan respon pemegang saham (Bahrun et al., 2020; Cheryta et al., 2018; Firmansyah, Setiawan, et al., 2020; Toly et al., 2019).

$\mathrm{H}_{1}$ : Cash holding berpengaruh negatif terhadap nilai perusahaan

Peningkatan ukuran dewan direksi dinilai berperan dalam kinerja suatu perusahaan karena akan menciptakan jaringan dengan pihak eksternal perusahaan (Hendratni et al., 2018). Dewan direksi juga dapat memastikan terjaminnya ketersediaan sumber daya untuk mencapai tujuan perusahaan (Hendratni et al., 2018). Di sisi lain, semakin banyak ukuran dewan direksi juga dapat menimbulkan masalah keagenan dimana semakin banyak agen-agen yang memiliki tujuan untuk mendapatkan gaji dan bonus yang besar (Carolina et al., 2020). Kondisi tersebut bertentangan dengan tujuan dari pemilik perusahaan yaitu untuk mendapatkan return yang sebesar-besarnya dari investasi yang telah dialirkan ke perusahaan. Adanya informasi asimetri antara manajer dan pemegang saham mengakibatkan adanya perbedaan kepentingan yang menguntungkan manajer. Manajer memiliki informasi yang lebih baik dibandingkan dengan pemegang saham (Firmansyah, Jadi, \& Sukarno, 2021).

Carolina et al. (2020), Utomo \& Dianawati (2017) menemukan bahwa ukuran dewan direksi berpengaruh negatif terhadap nilai perusahaan. Perusahaan dengan ukuran dewan yang lebih besar menunjukkan jumlah manajer yang lebih banyak dalam menjalankan perusahaan. Selain itu, dewan direksi yang semakin banyak dapat menyeleraskan kepentingan mereka sendiri berdasarkan motif tertentu yang telah disepakati bersama. Akibatnya informasi asimetri antara manajer dan pemegang saham semakin besar. Adanya jumlah dewan direksi yang lebih banyak seharusnya dapat meningkatkan kinerja dari perusahaan, apalagi perusahaan yang termasuk dalam skala besar. Masing-masing direksi memiliki tanggung jawab dan keahlian spesifik sehingga direksi dapat menjalankan perusahaan dengan lebih baik. Di sisi lain, adanya kesepakatan tertentu yang dijalankan oleh anggota dewan direksi mengakibatkan pemegang saham tidak selalu memiliki keyakinan atas kinerja yang telah dicapai oleh perusahaan dalam sejalan dengan harapan dari pemegang saham.

$\mathrm{H}_{2}$ : Dewan direksi berpengaruh negatif terhadap nilai perusahaan 
Penggunaan utang dengan tingkat bunga yang lebih tinggi memudahkan manajer untuk mendapatkan sumber pendanaan perusahaan (Firmansyah, Fauzi, et al., 2020). Perusahaan akan lebih mudah untuk memenuhi persyaratan dalam mendapatkan sumber pendanaan dari utang utang. Kreditor mengharapkan tingkat pengembalian dalam bentuk bunga yang lebih tinggi untuk mengkompensari adanya risiko pengembalian utang. Sementara itu, utang dengan tingkat bunga yang lebih rendah memberikan persyaratan yang lebih ketat (Firmansyah, Fauzi, et al., 2020). Ketika perusahaan lebih banyak menggunakan utang dalam sumber pendanaannya menunjukkan bahwa perusahaan memiliki risiko yang lebih besar (Firmansyah, Andriani, \& Mahrus, 2021; Jananto \& Firmansyah, 2019; Purwaka et al., 2022; Salman et al., 2020). Adanya diskresi manajer dalam memilih sumber pendanaan mengakibatkan berkurangnya tingkat keyakinan kreditor. Kondisi ini mengakibatkan turunnya respon investor yang ditunjukkan dalam penurunan harga saham perusahaan (Nasution, 2020). Kondisi ini akan lebih buruk lagi apabila perusahaan memiliki jumlah cash holding yang lebih besar. Perusahaan dianggap memegang uang kas hanya untuk melunasi kewajiban jatuh temponya saja, seharusnya perusahaan menggunakan utang dan jumlah kas yang dimiliki untuk mengembangkan investasi perusahaan.

$\mathrm{H}_{3}$ : Leverage memperkuat pengaruh negatif cash holding terhadap nilai perusahaan

Manajer cenderung menggunakan pendanaan dari utang dibandingkan saham untuk menghindari monitoring yang lebih besar dari pemegang saham (Utama et al., 2021). Kondisi ini mengakibatkan informasi asimetri yang semakin besar. Manajer cenderung lebih transparan kepada kreditur dengan alasan untuk memudahkan dalam memperoleh pendanaan dari utang (Firmansyah, Fauzi, et al., 2020). Di sisi lain, kreditor mengharapkan tingkat pengembalian berupa bunga dari utang yang diberikan kepada perusahaan. Persyaratan kredit yang lebih mudah mengakibatkan tingkat bunga menjadi tinggi karena perusahaan dianggap lebih beresiko.

Perusahaan akan melakukan tindakan yang lebih oportunistik dengan jumlah dewan direksi yang lebih banyak. Adanya penyatuan kepentingan di antara anggota dewan direksi mengakibatkan bahwa seluruh anggota dewan direksi memiliki kesamaan kepentingan. Selain itu, jumlah dewan direksi yang lebih besar mengakibatkan adanya tambahan biaya keagenan dengan penambahan atas jumlah beban gaji kepada manajer atau direksi.

$\mathrm{H}_{4}$ : Leverage memperkuat pengaruh negatif ukuran dewan direksi terhadap nilai perusahaan

\section{METODE}

Penelitian ini menggunakan data laporan keuangan dan harga saham perusahaan sektor barang konsumsi yang terdaftar di Bursa Efek Indonesia tahun 2015 sampai dengan tahun 2020. Sektor konsumsi merupakan salah satu sektor di Bursa Efek Indonesia yang tidak mengalami penurunan salah dalam mempengaruhi Indeks Harga Saham Gabungan (IHSG) selama tahun 2020 pada saat mulai adanya pandemi covid19 (Suryahadi, 2020). Sektor barang konsumsi menyediakan kebutuhan mendasar konsumen, sehingga mendorong retailer-retailer dengan konsep mini market yang tumbuh pesat sehingga berkontribusi dalam meningkatkan perekonomian di Indonesia (Syaikhon, 2014). Oleh karena itu, perusahaan sektor barang konsumsi yang terdaftar di BEI merupakan sektor perusahaan yang stabil di Indonesia. Data penelitian ini diambil dari www.finance.yahoo.com, www.idx.co.id, dan situs resmi perusahaan. 
Sampel yang digunakan dalam penelitian ini ditentukan dengan menggunakan purposive sampling dengan kriteria sebagai berikut:

Tabel 1 Sampel Penelitian

\begin{tabular}{lr}
\hline \multicolumn{1}{c}{ Kriteria } & Jumlah \\
\hline Perusahaan manufaktur yang terdaftar di BEI pada November 2021 & 208 \\
Perusahaan manufaktur yang bukan termasuk sektor barang konsumsi & -144 \\
Perusahaan manufaktur sektor barang konsumsi yang tidak terdaftar secara terus & \\
menerus dari tahun 2015-2020 & -41 \\
Perusahaan sektor barang konsumsi yang mengalami kerugian & -5 \\
Jumlah perusahaan yang dapat digunakan dalam penelitian & 18 \\
Jumlah tahun penelitian & 6 \\
Total sampel & 108 \\
\hline
\end{tabular}

Sumber: data diolah

Variabel dependen yang digunakan dalam penelitian ini adalah Nilai Perusahaan (Firm Value) yang diukur dengan menggunakan proksi Price to Book Value (PBV) dan Tobins' Q. Proksi PBV mengikuti (Febriana et al., 2018).

$$
\mathrm{PBV}=\frac{\text { harga saham akhir tahun }}{\text { nilai buku saham }}
$$

Proksi Tobins Q mengikuti (Febriana et al., 2018; Firmansyah, Setiawan, et al., 2020; Firmansyah \& Purnama, 2020).

$$
\text { Tobins }^{\prime} \mathrm{Q}=\frac{\text { market value of all outstanding shares }+\mathrm{debt}}{\text { total asset }}
$$

Dalam penelitian ini digunakan cash holding dan dewan direksi sebagai variabel independen. Proksi cash holding mengikuti (Firmansyah, Setiawan, et al., 2020) yaitu:.

$$
\text { Cash }=\frac{\text { Kas dan Setara Kas }}{\text { Total Aset }}
$$

Ukuran dewan direksi diukur menggunakan proksi jumlah anggota dewan direksi dalam suatu perusahaan sebagaimana (Sari \& Ardiana, 2014; Sondokan et al., 2019). Penelitian ini juga menggunakan leverage sebagai variabel moderasi. Proksi leverage diukur dengan menggunakan proksi Debt to Equity Ratio sebagaimana Firmansyah, Setiawan, et al. (2020)

$$
\text { DER }=\frac{\text { Total Debt }}{\text { Total Equity }}
$$

Selain menggunakan variabel moderasi, dalam penelitian ini juga digunakan variabel kontrol yang antara lain adalah ukuran perusahaan dan profitabilitas. Ukuran perusahaan diukur menggunakan proksi yang sama dengan penelitian yang dilakukan oleh Apriliyanti et al. (2019) dan Vernando \& Erawati (2020) yaitu log natural dari total aset perusahaan. Profitabilitas diukur dengan menggunakan return on assets sebagaimana Jaya (2020).

Dalam pengujian hipotesis pada penelitian ini digunakan analisis regresi berganda untuk data panel. Pengujian model dari regresi data panel dilakukan dengan menggunakan uji Chow, uji Hausman, dan uji Langrange Multiplier yang berfungsi untuk menentukan model terbaik untuk digunakan dalam penelitian ini antara common effect model, fix effect model, atau random effect model. Model penelitian utama yang digunakan dalam penelitian ini adalah sebagai berikut:

PBVit $=\alpha$ it $+\beta 1$ CASHit $+\beta 2$ MSIZEit $+\beta 3$ FIRMSIZEit $+\beta 4$ PROFit $+\varepsilon i t$ 
PBVit $=\alpha$ it $+\beta 1$ CASHit $+\beta 2$ MSIZEit $+\beta 3$ LEVit $+\beta$ 4CASHit $*$ LEVit $+\beta 5$ MSIZEit $*$ LEVit

$$
+\beta 6 \text { FIRMSIZEit }+\beta \text { PPROF it }+ \text { eit }
$$

Sedangkan model tambahan dalam penelitian ini adalah sebagai berikut:

$$
\begin{aligned}
\text { TOBINsQit }= & \alpha i t+\beta 1 \text { CASHit }+\beta 2 \text { MSIZEit }+\beta 3 \text { FIRMSIZEit }+\beta 4 \text { PROFit }+\varepsilon i t \ldots \\
\text { TOBINsQit }= & \alpha \text { it }+\beta 1 \text { CASHit }+\beta 2 \text { MSIZEit }+\beta 3 \text { LEVit }+\beta 4 \text { CASHit } * \text { LEVit }+\beta 5 \\
& * \text { LEVit }+\beta 6 \text { FIRMSIZEit }+\beta 7 \text { PROF it }+\varepsilon i t \ldots \ldots \ldots \ldots \ldots \ldots \ldots \ldots \ldots \ldots \ldots \ldots \ldots \ldots \ldots \ldots \ldots
\end{aligned}
$$$$
\text { TOBINsQit }=\alpha \text { it }+\beta 1 \text { CASHit }+\beta 2 \text { MSIZEit }+\beta \text { LLEVit }+\beta 4 \text { CASHit } * \text { LEVit }+\beta 5 \text { MSIZEit }
$$

$\begin{array}{ll}\text { PBV } & =\text { Nilai Perusahaan (PBV) } \\ \text { TOBIN'S Q } & =\text { Nilai Perusahaan (Tobin's Q) } \\ \text { CASH } & =\text { Cash holding } \\ \text { MSIZE } & =\text { Ukuran Dewan Direksi } \\ \text { LEV } & =\text { Leverage } \\ \text { FIRMSIZE } & =\text { Ukuran perusahaan } \\ \text { PROF } & =\text { Profitabilitas }\end{array}$

\section{HASIL DAN PEMBAHASAN}

Statistik deskriptif dari variabel penelitian ini terdapat dalam Tabel 2.

Tabel 2

Statistik Deskriptif

\begin{tabular}{cccccccc}
\hline & PBV & TOBIN'S Q & CASH & MSIZE & DER & FIRMSIZE & ROA \\
\hline Mean & 7,8892 & 4,0266 & 0,1792 & 5,6111 & 0,7205 & 28,1783 & 7,8225 \\
Median & 2,7267 & 2.3587 & 0,1696 & 5,0000 & 0,5173 & 28,8018 & 1,2015 \\
Std Dev & 14,9292 & 4,5436 & 0,1613 & 2,0271 & 0,6047 & 2,8846 & 11,8200 \\
Min & 0.000003 & 0,435195 & 0,000864 & 2.000000 & 0,076125 & 20,27955 & 0,000526 \\
Max & 82,44443 & 23,28575 & 1,236970 & 11.000000 & 3,159024 & 32,27145 & 52,62374 \\
Obs & 108 & 108 & 108 & 108 & 108 & 108 & 108 \\
\hline
\end{tabular}

Sumber: data diolah

Selanjutnya, Tabel 3 dan 4 merupakan ringkasan hasil uji hipotesis untuk persamaan 1, 2, 3, dan 4 di mana model yang paling fit untuk keempat model tersebut dengan menggunakan fixed effect model.

Tabel 3

Ringkasan Hasil Uji Hipotesis (Persamaan 1 dan 3)

\begin{tabular}{ccccccc}
\hline Variabel & \multicolumn{3}{c}{ PBV (Model Utama) } & \multicolumn{2}{c}{ Tobins Q (Model Tambahan) } \\
\cline { 2 - 6 } & Coeff & t-Stat & Prob. & Coeff & t-Stat & Prob. \\
\hline C & 2,047 & 0,150 & 0,881 & 8,129 & 1,030 & 0,306 \\
CASH & 2,292 & 1,889 & 0,062 & 0,705 & 1,978 & 0,051 \\
MSIZE & $-1,372$ & $-5,933$ & 0,000 & 0,120 & 1,366 & 0,175 \\
FirmSize & 0,423 & 0,848 & 0,399 & $-0,191$ & $-0,680$ & 0,498 \\
PROF & 0,152 & 6,063 & 0,000 & 0,063 & 7,396 & 0,000 \\
R $^{2}$ & & 0,799 & & & 0,942 & 0,928 \\
Adj R & & 0,751 & & & 67,037 & \\
F-Stat & & 16,337 & & & 0,000 & \\
Prob(F-stat) & 0,000 & & & &
\end{tabular}

Sumber: data diolah

Pengaruh Cash Holding Terhadap Nilai Perusahaan

Dari hasil pengujian model utama dan model tambahan menunjukkan bahwa cash holding berpengaruh positif terhadap nilai perusahaan. Hasil pengujian ini sejalan dengan Dewi et al. (2018), dan Yuliana (2020), namun tidak sejalan dengan Bahrun et al. (2020), Cheryta et al. (2018), Firmansyah, Setiawan, et al. (2020), dan Toly et al. (2019). Penelitian ini menunjukkan bahwa parameter kepemilikan kas yang dipegang oleh perusahaan memberikan 
kepercayaan kepada investor terkait dengan tingkat likuiditas perusahaan yang baik. Jumlah kas yang besar menunjukkan bahwa perusahaan dapat memenuhi kewajiban-kewajiban jatuh temponya, sehingga potensi terjadinya kesulitan keuangan dan potensi kebangkrutan di masa depan.

Selain itu, perusahaan memiliki atau memegang kas pada level yang tinggi bukan berarti bahwa perusahaan tersebut tidak memiliki strategi dalam memgembangkan investasinya baik dengan pengadaan aset tetap, investasi di perusahaan lain dan akuisisi. Selain itu, manajer lebih berhati-hati dalam investasi yang memiliki risiko yang tinggi karena manajer berusaha tetap berupaya untuk menjaga keberlangsung perusahaan di masa mendatang. Oleh karena itu, tindakan ini sejalan dengan harapan dari pemegang saham.

\section{Pengaruh Dewan Direksi Terhadap Nilai Perusahaan}

Hasil pengujian model utama menunjukkan ukuran dewan direksi berpengaruh negatif terhadap nilai perusahaan, sedangkan model tambahan menunjukkan bahwa ukuran dewan direksi tidak berpengaruh terhadap nilai perusahaan. Hasil pengujian ini sejalan dengan Carolina et al. (2020) dan Utomo \& Dianawati (2017), namun tidak sejalan dengan Mawei \& Tulung (2019), Sari \& Ardiana (2014), dan Sondokan et al. (2019). Di satu sisi, jumlah direksi yang lebih banyak dapat membuat pekerjaan lebih efisien karena adanya pemisahan fungsifungsi utama di dalam perusahaan. Anggota dewan direksi tidak melakukan pekerjaan yang bukan merupakan bidangnya karena tugas dan tanggung jawabnya berdasarkan fungsi atau bidang tertentu yang telah ditetapkan perusahaan. Di sisi lain, semakin banyak ukuran dewan direksi juga dapat menimbulkan masalah keagenan dimana semakin banyak anggota dewan direksi yang memiliki tujuan untuk mendapatkan gaji dan bonus yang besar (Carolina et al., 2020). Oleh karena itu, perusahaan akan menanggung beban gaji yang lebih besar.

Adanya informasi asimetri mengakibatkan manajer memiliki informasi yang lebih baik dibandingkan dengan pemegang saham (Firmansyah, Jadi, \& Sukarno, 2021). Perusahaan dengan ukuran dewan yang lebih banyak di dalam perusahaan mengakibatkan adanya penyatuan kepentingan atau motif tertentu yang dapat menguntungkan seluruh anggota dewan direksi. Selain itu, pemegang saham menganggap bahwa dewan direksi dapat menguasai beberapa bidang atau fungsi di dalam perusahaan, sehingga pekerjaan menjadi lebih efisien.

Tabel 4

Hasil Uji Regresi Berganda (Persamaan 2 dan 4)

\begin{tabular}{|c|c|c|c|c|c|c|}
\hline \multirow{2}{*}{ Variabel } & \multicolumn{3}{|c|}{ PBV (Model Utama) } & \multicolumn{3}{|c|}{ Tobins Q (Model Tambahan) } \\
\hline & Coeff & $\mathrm{t}-$ Stat & Prob. & Coeff & $\mathrm{t}-$ Stat & Prob. \\
\hline $\mathrm{C}$ & 23,249 & 0,901 & 0,370 & 5,749 & 0,627 & 0,532 \\
\hline $\mathrm{CASH}$ & 11,163 & 4,471 & 0,000 & 0,456 & 0,711 & 0,479 \\
\hline MSIZE & 0,165 & 0,478 & 0,633 & 0,154 & 1,366 & 0,176 \\
\hline LEV & 9,509 & 2,619 & 0,010 & $-0,028$ & $-0,032$ & 0,975 \\
\hline CASH*LEV & $-21,043$ & $-2,984$ & 0,003 & 0,425 & 0,213 & 0,831 \\
\hline MSIZE*LEV & $-0,857$ & $-1,849$ & 0,068 & $-0,093$ & $-0,699$ & 0,487 \\
\hline Firm Size & $-0,719$ & $-0,788$ & 0,433 & $-0,098$ & $-0,301$ & 0,764 \\
\hline PROF & 0,118 & 4,029 & 0,000 & 0,0623 & 6,795 & 0,000 \\
\hline R2 & & 0,782 & & & 0,946 & \\
\hline $\operatorname{Adj} \mathrm{R}^{2}$ & & 0,720 & & & 0,931 & \\
\hline F-Stat & & 12,461 & & & 60,781 & \\
\hline $\operatorname{Prob}(\mathrm{F}$-stat) & & 0,0000 & & & 0,000 & \\
\hline
\end{tabular}

Sumber: data diolah 


\section{Peran Leverage Atas Pengaruh Cash Holding Terhadap Nilai Perusahaan}

Hasil pengujian pada model utama menunjukkan bahwa interaksi antara cash holding dan leverage berpengaruh negatif terhadap nilai perusahaan. Berkaitan dengan pengujian sebelumnya, hasil pengujian ini menunjukkan bahwa leverage memperlemah pengaruh positif cash holding terhadap nilai perusahaan. Penggunaan proporsi utang dalam struktur pendanaan perusahaan yang lebih tinggi menunjukkan adanya diskresi kebijakan manajer dalam memilih sumber pendanaan perusahaan. Utang yang diperoleh perusahaan dengan persyaratan yang mudah berkaitan dengan tingkat bunga yang lebih tinggi (Firmansyah, Fauzi, et al., 2020). Hal ini merupakan kompensasi dari kreditur dalam memberikan pinjamannya kepada perusahaan.

Tingkat hutang yang lebih tinggi dapat menurunkan keyakinan investor terkait dengan masa depan perusahaan (Nasution, 2020). Selain itu, penggunaan utang yang lebih besar dibandingkan dengan ekuitas dalam sumber pendanaan perusahaan, persyaratan yang diberikan oleh kreditur diduga lebih mudah. Namun, hal ini mengakibatkan perusahaan dalam kondisi yang lebih beresiko (Firmansyah, Andriani, \& Mahrus, 2021; Jananto \& Firmansyah, 2019; Purwaka et al., 2022; Salman et al., 2020). Struktur pendanaan dengan utang yang lebih besar menurunkan respon positif investor atas jumlah kas yang dimiliki oleh perusahaan. Investor menganggap bahwa jumlah kas yang dimiliki oleh perusahaan digunakan hanya untuk memenuhi kewajiban perusahaan yang akan jatuh tempo seperti membayar pokok pinjaman dan beban bunga perusahaan. Padahal investor mengharapkan bahwa jumlah kas yang dimiliki oleh perusahaan dapat digunakan untuk pengadaan aset tetap ataupun investasi yang dapat memberikan keuntungan perusahaan di masa depan.

\section{Peran Leverage Atas Pengaruh Ukuran Dewan Direksi Terhadap Nilai Perusahaan}

Hasil pengujian pada model utama menunjukkan bahwa interaksi antara leverage dan ukuran dewan direksi berpengaruh negatif terhadap nilai perusahaan. Berkaitan dengan pengujian sebelumnya, leverage memperkuat pengaruh negatif ukuran dewan direksi terhadap nilai perusahaan. Penggunaan utang dalam sumber pendanaan perusahaan, perusahaan memiliki potensi atas kesulitan keuangan atau bahkan kebangkrutan di masa mendatang (Jananto \& Firmansyah, 2019). Perusahaan dituntut untuk selalu memenuhi kewajibannya dalam pembayaran pokok pinjaman dan beban bunganya. Dalam kondisi yang kurang menguntungkan, perusahaan akan tetap dikenakan pembayaran kewajibannya kepada kreditur. Kondisi ini dapat mengakibatkan kurangnya likuiditas perusahaan, sehingga kewajiban perusahaan jatuh tempo yang tidak dapat dipenuhi berakibat perusahaan dikenakan denda atas pokok pinjaman dan beban bunga yang tertunggak (Firmansyah, Sihombing, et al., 2020). Hal ini mengakibatkan adanya akumulasi jumlah pinjaman yang lebih besar. Kondisi ini berbeda atas kewajiban pembayaran dividen kepada pemegang saham yang lebih fleksibel terkait dengan kondisi keuangan perusahaan.

Potensi ketidakmampuan perusahaan dalam memenuhi kewajibannya di masa mendatang dapat mengancam kelangsungan perusahaan di masa mendatang. Selain itu, penggunaan utang yang lebih besar dapat meningkatkan informasi asimetri antara manajer dan pemegang saham (Firmansyah, Fauzi, et al., 2020). Sementara itu, adanya jumlah dewan direksi yang lebih banyak dapat menurunkan nilai perusahaan karena pemegang saham menganggap bahwa perusahaan akan memiliki kinerja yang sama apabila jumlah dewan direksi lebih rendah. Pemegang saham menganggap bahwa anggota dewan direksi di Indonesia memiliki 
pengalaman dan latar belakang pekerjaan bukan hanya satu bidang saja, sehingga satu anggota dewan direksi dapat memiliki keahlian bukan hanya di satu bidang saja. Adanya jumlah dewan direksi yang lebih banyak dianggap perusahaan kurang efisien khususnya dalam menekan biaya gaji pegawai. Kondisi dapat diperparah dengan struktur pendanaan utang yang lebih besar. Dalam kondisi demikian, keyakinan pemegang saham atas keberlangsungan perusahaan di masa mendatang menjadi berkurang.

\section{PENUTUP}

\section{Simpulan}

Penelitian ini menemukan bahwa kepemilikan kas yang lebih besar mendapat respon positif dari pemegang saham karena perusahaan dianggap lebih berhati-hati dalam mengeluarkan kas. Manajer dianggap mampu berinvestasi pada kegiatan-kegiatan yang dapat menguntungkan perusahaan. Sementara itu, jumlah dewan direksi yang semakin besar menunjukkan bahwa perusahaan dianggap kurang efisien dalam pengeluaran biaya gaji manajer. Padahal dengan jumlah dewan direksi yang lebih kecil, perusahaan akan memiliki kinerja yang sama atau bahkan lebih baik. Selanjutnya, kepemilikan utang yang lebih besar dalam struktur pendanaan perusahaan dianggap lebih beresiko oleh pemegang saham. Perusahaan memiliki potensi kesulitan keuangan atau bahkan potensi kebangkrutan di masa mendatang apabila perusahaan memiliki utang yang lebih besar dibandingkan dengan ekuitasnya. Kepemilikan utang yang lebih besar dapat menurunkan peran positif atas kepemilikan kas oleh perusahaan dan menurunkan kepercayaan investor atas jumlah dewan direksi yang lebih besar dalam pandangan pemegang saham.

\section{Saran}

Keterbatasan penelitian ini adalah data yang digunakan dalam penelitian ini relatif sedikit dan hanya menggunakan data perusahaan sektor konsumsi yang terdaftar di Bursa Efek Indonesia. Penelitian selanjutnya dapat menggunakan data perusahaan sektor non keuangan dan dengan jumlah data yang lebih besar untuk mendapatkan hasil pengujian yang lebih baik dan lebih representatif. Penelitian ini mengindikasikan bahwa Otoritas Jasa Keuangan perlu meningkatkan pengaturan tata kelola perusahaan terkait dengan tugas dan fungsi dewan direksi dalam perusahaan yang terdaftar di BEI dan pengaturan atas kepemilikan utang dalam pendanaan perusahaan. Kebijakan ini mendorong perlindungan investor dan calon investor di pasar modal Indonesia.

\section{DAFTAR PUSTAKA}

Al 'Alam, M. P. A., \& Firmansyah, A. (2019). The effect of financial reporting quality, debt maturity, political connection, and corporate governance on investment efficiency: evidence from Indonesia. International Journal of Innovation, Creativity and Change, 7(6), 39-56. https://www.ijicc.net/images/vol7iss6/7603_Alam_2019_E_R.pdf

Amalia, A. R., Rahmawati, F., Amalia, S. L. R., \& Sugiyanto, S. (2021). Pengaruh sustainability reporting terhadap nilai perusahaan dengan kinerja keuangan sebagai variabel moderating. Humanities, Management, and Science Proceeding, 1(2), 130-140. http://openjournal.unpam.ac.id/index.php/SNH/article/view/11212

Apriliyanti, V., Hermi, H., \& Herawaty, V. (2019). Pengaruh kebijakan hutang, kebijakan dividen, profitabilitas, pertumbuhan penjualan dan kesempatan investasi terhadap nilai 
perusahaan dengan ukuran perusahaan sebagai variabel moderasi. Jurnal Magister Akuntansi Trisakti, 6(2), 201. https://doi.org/10.25105/jmat.v6i2.5558

Bahrun, M. F., Tifah, T., \& Firmansyah, A. (2020). Pengaruh keputusan pendanaan, keputusan investasi, kebijakan dividen, dan arus kas bebas terhadap nilai perusahaan. Jurnal Ilmiah Akuntansi Kesatuan, 8(3), 263-276. https://doi.org/10.37641/jiakes.v8i3.358

Bing, T., \& Li, M. (2019). Does CSR signal the firm value? Evidence from China. Sustainability, 11(15), 1-22. https://doi.org/10.3390/su11154255

Carolina, C., Vernnita, V., \& Christiawan, Y. J. (2020). Pengaruh hutang terhadap nilai perusahaan dengan ukuran perusahaan sebagai variabel moderasi. Business Accounting Review, $\quad 8(2), \quad 30-44 . \quad$ https://publication.petra.ac.id/index.php/akuntansibisnis/article/view/11797

Cheryta, A. M., Moeljadi, M., \& Indrawati, N. K. (2018). Leverage, asymmetric information, firm value, and cash holdings in Indonesia. Jurnal Keuangan Dan Perbankan, 22(1), 8393. https://doi.org/10.26905/jkdp.v22i1.1334

Dewi, D. K., Tanjung, A. R., \& Indrawati, N. (2018). Analisis pengaruh free cash flow, investment opportunity set, ukuran perusahaan dan kepemilikan manajerial terhadap nilai perusahaan dengan kebijakan hutang sebagai variabel moderating (Studi pada perusahaan manufaktur yang listing di Bursa Efek Indonesia. Jurnal Ekonomi, 26(2), 101-121. https://doi.org/10.31258/je.26.2.p.101-121

Dresti, A., \& Putri, F. D. (2021). Analisis perbandingan pengaruh pengungkapan dan transaksi pihak berelasi terhadap nilai perusahaan pada sektor properti. Jurnalku, 1(2), 70-84. https://jurnalku.org/index.php/jurnalku/article/view/17

Febriana, M., Panjaitan, F., \& Astuti, N. (2018). Analisa pengaruh cash holding, kebijakan dividen dan financial risk terhadap nilai perusahaan perusahaan manufaktur. Jurnal Ilmiah Akuntansi Bisnis \& Keuangan, 13(1), 63-73. https://e-jurnal.stieibek.ac.id/index.php/JIABK/article/view/355

Firmansyah, A., Andriani, A. F., \& Mahrus, M. L. (2021). Biaya modal perusahaan di Indonesia: tanggung jawab sosial dan tata kelola perusahaan. Jurnal Ekonomi, 26(3), 361378. https://doi.org/10.24912/je.v26i3.796

Firmansyah, A., \& Ardi, A. K. (2020). Related party transactions, supply chain and cost management on firm's value: Evidence from Indonesia. International Journal of Supply Chain Management, 9(3), 1201-1209. http://ojs.excelingtech.co.uk/index.php/IJSCM/article/view/5026

Firmansyah, A., Fauzi, I., \& Rizal Yuniar, M. (2020). Biaya utang dari sudut pandang kebijakan dividen, volatilitas laba, dan kualitas akrual. Akurasi: Jurnal Studi Akuntansi Dan Keuangan, 3(2), 109-129. https://doi.org/10.29303/akurasi.v3i2.54

Firmansyah, A., Febrian, W., Jadi, P. H., Husna, M. K., \& Putri, M. A. (2021). Respon investor atas tanggung jawab sosial tata kelola perusahaan di Indonesia: perspektif resource based view. E-Jurnal Akuntansi, $\quad 31(8), \quad 1918-1935$. https://doi.org/10.24843/EJA.2021.v31.i08.p04

Firmansyah, A., Husna, M. C., \& Putri, M. A. (2021). Corporate social responsibility disclosure, corporate governance disclosures, and firm value in Indonesia chemical, plastic, and packaging sub-sector companies. Accounting Analysis Journal, 10(1), 9-17. https://doi.org/10.15294/aaj.v10i1.42102

Firmansyah, A., Jadi, P. H., Febrian, W., \& Fasita, E. (2021). Respon pasar atas pengungkapan emisi karbon di Indonesia: bagaimana peran tata kelola perusahaan? Jurnal Magister $\begin{array}{lll}\text { Akuntansi Trisakti, } & \text { 8(2), } & \text { 151-170. }\end{array}$ https://trijurnal.lemlit.trisakti.ac.id/jmat/article/view/9789

Firmansyah, A., Jadi, P. H., \& Sukarno, R. S. (2021). Bagaimana respon investor terhadap 
kepemilikan saham oleh CEO? Jurnal Online Insan Akuntan, 4(1), 15-28. https://ejournalbinainsani.ac.id/index.php/JOIA/article/view/1476

Firmansyah, A., \& Purnama, E. B. D. (2020). Do derivatives instruments ownership decrease firm value in Indonesia? Riset Akuntansi Dan Keuangan Indonesia, 5(1), 1-9. https://doi.org/10.23917/reaksi.v5i1.9817

Firmansyah, A., Setiawan, T. A., \& Fathurahman, F. (2020). Nilai perusahaan: kebijakan utang, good corporate governance, cash holding. Jurnal Akuntansi Dan Bisnis, 20(2), 237. https://doi.org/10.20961/jab.v20i2.568

Firmansyah, A., Sihombing, P., \& Kusumastuti, S. Y. (2020). The determinants of idiosyncratic volatility in Indonesia banking industries. Jurnal Keuangan Dan Perbankan, 24(2), 175188. https://doi.org/10.26905/jkdp.v24i2.3851

Firmansyah, A., \& Triastie, G. A. (2020). The role of corporate governance in emerging market: Tax avoidance, corporate social responsibility disclosures, risk disclosures, and investment efficiency. Journal of Governance and Regulation, 9(3), 8-26. https://doi.org/10.22495/jgrv9i3art1

Firmansyah, A., Utami, W., Umar, H., \& Mulyani, S. D. (2020). The role of derivative instruments on risk relevance from emerging market non-financial companies. Journal of Governance and Regulation, 9(3), 45-63.

Gaol, G. A. L., Firmansyah, A., \& Irawati, A. D. (2021). Intellectual capital, corporate social responsibility, and firm value in Indonesia's banking industries. Jurnal Riset Akuntansi Terpadu, 14(1), 76-87. https://doi.org/110.35448/jrat.v14i1.10229

Hadi, N., Sheila, S., Firmansyah, A., \& Trisnawati, E. (2021). Respon pasar atas pengungkapan keberlanjutan pada perusahan perbankan di indonesia: peran ukuran perusahaan. Bina Ekonomi, 25(2), 97-111. https://doi.org/10.26593/be.v25i2.5339.97-111

Haryanto, S., Rahadian, N., Mbapa, M. F. I., Rahayu, E. N., \& Febriyanti, K. V. (2018). Kebijakan hutang, ukuran perusahaan dan kinerja keuangan terhadap nilai perusahaan: industri perbankan di Indonesia. AFRE (Accounting and Financial Review), 1(2), 62-70. https://doi.org/10.26905/afr.v1i2.2279

Hendratni, T. W., Nawasiah, N., \& Indriati, T. (2018). Analisis pengaruh corporate governance terhadap kinerja keuangan sektor perbankan yang terdaftar di BEI Tahun 2012-2016. Jurnal Riset Manajemen Dan Bisnis (JRMB) Fakultas Ekonomi UNIAT, 3(1), 37-52. https://doi.org/10.36226/jrmb.v3i1.83

Hertina, D., Hidayat, M. B. H., \& Mustika, D. (2019). Ukuran perusahaan, kebijakan hutang dan profitabilitas pengaruhnya terhadap nilai perusahaan. Jurnal Ecodemica, 3(1), 1-10. https://doi.org/10.31294/jeco.v3i1.5456

Ihsani, M. A., Firmansyah, A., \& Estutik, R. S. (2021). Market response to companies sustainability disclosure and environmental performance in Indonesia. Jurnal Dinamika Akuntansi Dan Bisnis, 8(2), 197-214. https://doi.org/10.24815/jdab.v8i2.21630

Irawan, F., \& Turwanto, T. (2020). The effect of tax avoidance on firm value with tax risk as moderating variable. Test Engineering and Management, 83(March-April), 9696-9707. https://www.testmagzine.biz/index.php/testmagzine/article/view/5365/4340

Jamil, S., Erinos, N., \& Afriyenti, M. (2019). Pengaruh kepemilikan institusional terhadap nilai perusahaan dimoderasi oleh corporate social responsibility. Jurnal Eksplorasi Akuntansi, 1(1), 487-503. https://doi.org/10.24036/jea.v1i1.89

Jananto, A. E., \& Firmansyah, A. (2019). The effect of bonuses, cost of debt, tax avoidance, and corporate governance on financial reporting aggressiveness: evidence from Indonesia. International Journal of Innovation, Creativity and Change, 7(5), 280-302.

Jaya, S. (2020). Ukuran Perusahaan (Firm Size) dan Profitabilitas (ROA) Terhadap Nilai Perusahaan (Firm Value) Pada Perusahaan Sub Sektor Property dan Real Estate di Bursa 
Kieso, D. E., Weygandt, J. J., \& Warfield, T. D. (2018). Intermediate accounting: IFRS Edition, 3rd Edition. John Wiley \& https://www.google.co.id/books/edition/Intermediate_Accounting/VXH5twEACAAJ?hl $=$ en

Kurniawan, V., \& Firmansyah, A. (2019). The effect of tax uncertainty, stock market liquidity, earnings management on Indonesian firm's investment. Jurnal Manajemen Teknologi, 18(2), 106-119. https://doi.org/10.12695/jmt.2019.18.2.2

Kusuma, A. W., \& Priantinah, D. (2018). Pengaruh pengungkapan sustainability report dan ukuran perusahaan terhadap nilai perusahaan dengan profitabilitas sebagai variabel pemoderasi pada perusahaan yang bergabung di ISSI dan Konvensional periode 20142016. Jurnal Nominal, 7(2), 91-105. https://doi.org/10.21831/nominal.v7i2.21352

Machmuddah, Z., Sari, D. W., \& Utomo, S. D. (2020). Corporate social responsibility, profitability and firm value: Evidence from Indonesia. Journal of Asian Finance, $\begin{array}{llll}\text { Economics } \quad \text { and } & \text { Business, }\end{array}$ https://doi.org/10.13106/JAFEB.2020.VOL7.NO9.631

Mawei, M. F. ., \& Tulung, J. E. (2019). Pengaruh dewan direksi, ukuran perusahaan dan debt to equity ratio terhadap nilai perusahaan pada subsektor food and beverage yang terdaftar di Bursa Efek Indonesia. Jurnal EMBA: Jurnal Riset Ekonomi, Manajemen, Bisnis Dan Akuntansi, 7(3), 3249-3258. https://doi.org/10.35794/emba.v7i3.24207

Mubyarto, N. (2020). The influence of profitability on firm value with capital structure as the mediator. Journal Economia, 16(2), 184-199. https://doi.org/10.21831/economia.v16i2.30405

Nasution, M. S. (2020). Pengaruh kebijakan hutang terhadap nilai perusahaan perbankan yang terdaftar di Bursa Efek Indonesia. J-ISCAN: Journal Of Islamic Accounting Research, 2(1), 1-16. https://media.neliti.com/media/publications/338826-pengaruh-kebijakanhutang-terhadap-nilai-7462835e.pdf

Novianti, T., \& Firmansyah, A. (2020). The effect of tax risk, hedging, income smoothing, and cash flows volatility on firm value. Test Engineering and Management, 83(April), 96759686. https://www.testmagzine.biz/index.php/testmagzine/article/view/5362

Nuryono, M., Wijayanti, A., \& Samrotun, Y. C. (2019). Pengaruh kepemilikan manajerial, kepemilikan institusional, komisaris independen, komite audit, serta kulitas audit pada nilai perusahaan. Edunomika, 03(01), 199-212. https://doi.org/10.29040/jie.v3i01.457

Permatasari, M., Melyawati, M., Firmansyah, A., \& Trisnawati, E. (2021). Peran konsentrasi kepemilikan : respon investor, penghindaran pajak, manajemen laba. Studi Akuntansi Dan Keuangan Indonesia, 4(1), 17-29. https://doi.org/10.21632/saki.4.1.17-29

Purwaka, A. J., Firmansyah, A., Qadri, R. A., \& Dinarjito, A. (2022). Cost of capital, corporate tax plannings, and corporate social responsibility disclosure. Jurnal Akuntansi, 26(1), 122. https://doi.org/10.24912/ja.v26i1.814

Putra, A. R., \& Rahmawati, S. (2016). Pengaruh mekanisme corporate governance dan cash holding terhadap nilai perusahaan manufaktur di Indonesia. Jurnal Ilmiah Mahasiswa Ekonomi Manajemen, 1(1), 92-109. http://jim.unsyiah.ac.id/EKM/article/view/62

Putri, M. M., Firmansyah, A., \& Labadia, D. (2020). Corporate social responsibility disclosure, good corporate governance, firm value: evidence from Indonesia's food and beverage companies. The Accounting Journal of Binaniaga, 5(2), 113. https://doi.org/10.33062/ajb.v5i2.398

Rahman, M. A. I., Domas, Z. K. S., \& Firmansyah, A. (2021). Hubungan pengungkapan keberlanjutan dan nilai perusahaan : kasus perusahaan sub sektor perbankan di Indonesia. 
Jurnalku, 1(4), 390-399. https://doi.org/10.54957/jurnalku.v1i4.105

Salman, I., Firmansyah, A., \& Widyaningrum, M. R. (2020). Peran leverage sebagai pemoderasi: revaluasi aset tetap, kebijakan dividen, nilai perusahaan. Jurnal Magister Akuntansi Trisakti, 7(2), 171. https://doi.org/10.25105/jmat.v7i2.7810

Sari, A. . P. A. M. P., \& Ardiana, P. A. (2014). Pengaruh board size terhadap nilai perusahaan. E-Jurnal Akuntansi Universitas Udayana, 7(1), 177-191. https://ojs.unud.ac.id/index.php/Akuntansi/article/view/8654

Scott, W. R. (2015). Financial accounting theory seventh edition. Prentice-Hall, Inc.

Sondokan, N. V, Koleangan, R., \& Karuntu, M. M. (2019). Pengaruh dewan komisaris independen, dewan direksi, dan komite audit terhadap nilai perusahaan yang terdaftar di Bursa Efek Indonesia Periode 2014-2017. Jurnal EMBA: Jurnal Riset Ekonomi, Manajemen, Bisnis Dan Akuntansi, 7(4), 5821-5830. https://doi.org/10.35794/emba.v7i4.26517

Suhanda, N. H., Hidayat, A. N., \& Firmansyah, A. (2019). Firm value and performances in merger policy: evidence from Indonesia. Academy of Accounting and Financial Studies Journal, 23(2), 1-12. https://www.abacademies.org/articles/firm-value-andperformances-in-merger-policy-evidence-from-indonesia-8128.html

Suryahadi, A. (2020). Sektor barang konsumsi jadi jawara sejak awal tahun, simak rekomendasi analis berikut. Kontan.Co.Id. https://investasi.kontan.co.id/news/sektorbarang-konsumsi-jadi-jawara-sejak-awal-tahun-simak-rekomendasi-analis-berikut-1

Syaikhon, A. (2014). Menangkap keuntungan di industri barang konsumsi. Www.Neraca.Co.Id. https://www.neraca.co.id/article/37815/menangkap-keuntungan-diindustri-barang-konsumsi

Toly, A. A., Claudya, C., Santoso, R., \& Grace, F. (2019). Analisa pengaruh corporate governance, ownership structure, dan cash on hand terhadap nilai perusahaan. Jurnal Riset Keuangan Akuntansi, 5(2), 31-51. https://doi.org/10.25134/jrka.v5i2.2006

Utama, Y. W., Syakur, A., \& Firmansyah, A. (2021). Opini audit going concern: sudut pandang likuiditas, leverage, financial distress risk, tax risk. Jurnal Al-Iqtishad, 17(1), 129-147. http://ejournal.uin-suska.ac.id/index.php/al-iqtishad/article/view/12657

Utomo, F. M., \& Dianawati, W. (2017). Corporate governance dan leverage terhadap nilai perusahaan dengan kualitas laba sebagai variabel mediasi. Jurnal Investasi Islam, 2(2), 21-44. https://journal.iainlangsa.ac.id/index.php/jii/article/view/276

Vernando, J., \& Erawati, T. (2020). Pengaruh ukuran perusahaan terhadap nilai perusahaan dengan struktur modal sebagai variabel intervening: studi empiris BEI. Jurnal Riset Manajemen Dan Bisnis, 15(1), 13. https://doi.org/10.21460/jrmb.2020.151.344

Widianingsih, D. (2018). Kepemilikan manajerial, kepemilikan institusional, komisaris independen, serta komite audit pada nilai perusahaan dengan pengungkapan csr sebagai variabel moderating dan firm size sebagai variabel kontrol. Jurnal Akuntansi Dan Pajak, 19(1), 38. https://doi.org/10.29040/jap.v19i1.196

Widodo, T. T., \& Firmansyah, A. (2021). Does investors respond to tax avoidance and tax risk? Bina Ekonomi, 25(1), 23-40. https://doi.org/10.26593/be.v25i1.5123.23-40

Yuliana, T. (2020). Pengaruh free cash flow, dan harga saham terhadap nilai perusahaan dengan kebijakan deviden sebagai variabel intervening (Prosiding Seminar Nasional Pakar Ke 3). https://www.trijurnal.lemlit.trisakti.ac.id/pakar/article/view/6887 